\title{
Efficient Synthesis and Intramolecular Cyclopropanation of Unsaturated Diazoacetic Esters
}

\section{Citation}

Corey, Elias J., and Andrew G. Myers. 1984. Efficient synthesis and intramolecular

cyclopropanation of unsaturated diazoacetic esters. Tetrahedron Letters 25(33): 3559-3562.

\section{Published Version}

http://dx.doi.org/10.1016/S0040-4039(01)91075-5

\section{Permanent link}

http://nrs.harvard.edu/urn-3:HUL.InstRepos:2958236

\section{Terms of Use}

This article was downloaded from Harvard University's DASH repository, and is made available under the terms and conditions applicable to Other Posted Material, as set forth at http:// nrs.harvard.edu/urn-3:HUL.InstRepos:dash.current.terms-of-use\#LAA

\section{Share Your Story}

The Harvard community has made this article openly available.

Please share how this access benefits you. Submit a story.

Accessibility 


\section{E FFICIENT SYNTHESIS AND INT RAMOLECULAR CYCLOPROPANATION OF UNSATURATED DIAZOACETIC ESTERS}

E. J. Corey and Andrew G. Myers

Department of Chemistry, Harvard University, Cambridge, Massachusetts 02138

Summary: New and efficlent procedures are described for the conversion of homoallylic alcohols to esters of diazoacetic acid and for the further intramolecular cyclopropanation of those esters.

As part of a program directed towards the synthesis of the antheridiogen of Anemia phyllitidis, ${ }^{A}{ }_{\text {An }}{ }^{1}$ we required an efficient means of transforming alcohol $\underset{\sim}{1}$ via its dlazoester $\underset{\sim}{2}$, to cyclopropyllactone 3. The method of House and Blankley which involves the reaction of glyoxylic acid chloride $\mathrm{p}$-toluenesulfonylhydrazone and triethylamine with an alcohol, has been widely used for the preparation of diazoacetic esters. ${ }^{2}$ Application of this procedure to a model substance, the alcohol ${\underset{\sim}{4}}^{3}$ afforded at

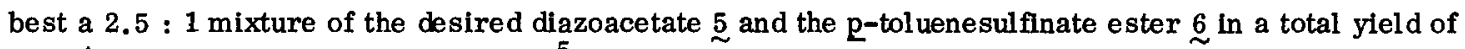
$65 \%{ }^{4}$ An examination of the literature as well as our experience with the reaction suggest that this side reaction may be general and that achlevable yields are in the range $40-55 \%$ (as in the preparation of crotyl diazoacetate ${ }^{6}$ ). The formation of p-toluenesulfinate ester can be rationalized as the result of a process such as the following:

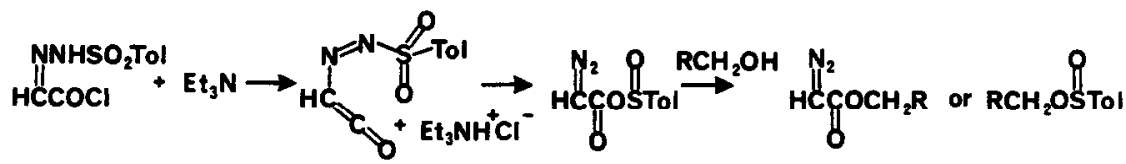

Indeed, infrared analysis demonstrated that triethylamine promotes the conversion of glyoxylic acid chloride tosylhydrazone to a diazo compound within a few minutes at room temperature in methylene chloride. In order to circumvent this base induced side reaction the use of a weaker base, $\mathrm{N}, \mathrm{N}$-dimethylaniline, in the reaction was examined. It was found that dimethylaniline promotes clean reaction between glyoxylic acid chloride tosylhydrazone and alcohols to form the corresponding esters (detected by thin layer chromatography-tlc) which upon further reaction (in situ) with triethylamine are converted to diazoacetic esters. Thus the alcohol $\underset{\sim}{4}$ was converted to diazo ester $\underset{\sim}{5}$ in $70 \%$ isolated yield with no detectable sulfinate by-product $\underset{\sim}{6}$ by tlc analysis. Use of this modified procedure has provided the pure diazoacetate of 3-vinylcyclohex-2-enol, $\underset{7}{\sim}(76 \%)$, and (1R, 2S, 5R)-2-(dimethylbenzyl)-5-methyl-cyclohexanol, $\underset{\sim}{\sim},(77 \%)$. 
The method is illustrated in the preparation of diazoester 2 .

Thermal decomposition of diazoester 2 using a stirred suspension of copper powder in toluene at reflux afforded cyclopropyllactone $\underset{\sim}{3}$ in $57 \%$ yleld. However, it was found that the yield of $\underset{\sim}{3}$ dropped substantially on scale-up evldently as a consequence of the hetereogeneous reaction conditions. Use of bis-(N-t-butyl salicylal diminato) copper (II), a soluble catalyst, ${ }^{10}$ coupled with slow introduction of diazoester into the reaction mixture afforded an excellent yield of cyclopropyllactone $\underset{\sim}{\mathbf{3}}$ regardless of scale. This procedure also provided lactone 10 from dlazoester $\underset{\sim}{9}$ in $92 \%$ yleld.

Diazoester 2: Glyoxylic acid chloride p-toluenesul fonylhydrazone ${ }^{6}(15.2 \mathrm{~g}, 58.3 \mathrm{mmol})$ was added to an ice-cooled solution of dry alcohol $\underset{\sim}{1}$ (a $1: 1$ mixture of epimers, as shown, $10.51 \mathrm{~g}, 31.2$ $\mathrm{mmol})$ in $180 \mathrm{~mL}$ of dry methylene chloride under an argon atmosphere. Dimethylaniline $(7.25 \mathrm{~mL}$, $57.2 \mathrm{mmol}$ ) was added and the dark green solution was stirred for $15 \mathrm{~min}$ prior to injection of triethylamine $(22 \mathrm{~mL}, 160 \mathrm{mmol})$. The resulting dark orange suspension was stirred $10 \mathrm{~min}$ at $0^{\circ}$ then for 15 $\mathrm{min}$ at room temperature before water $(125 \mathrm{~mL})$ was introduced and the mixture was concentrated $\underline{\text { in }}$ vacuo. Saturated aqueous citric acid $(250 \mathrm{~mL})$ and $10 \%$ ethyl acetate-hexanes $(250 \mathrm{~mL})$ were added and the layers were separated. The organic layer was washed with $250 \mathrm{~mL}$ citric acid solution and the combined aqueous layers were extracted with $100 \mathrm{~mL} \mathrm{10 \%} \mathrm{ethyl} \mathrm{acetate-hexanes.} \mathrm{This} 100 \mathrm{~mL}$ extract was washed with an equal volume of citric acid solution and the combined organlc layers were dried over sodium sulfate. Concentration and flash chromatography ${ }^{9}(5 \%$ ethyl acetate-hexanes) provided 2 as a yellow syrup $(11.44 \mathrm{~g}, 90.5 \%) ;{ }^{1} \mathrm{H}$ NMR $\left(270 \mathrm{MHz} \mathrm{CDCl}_{3}\right): \delta 5.75(\mathrm{~m}, 1 \mathrm{H}), 5.46(\mathrm{~m}, 1 \mathrm{H}), 5.07$ and $5.09(\mathrm{~s}, 1 \mathrm{H})$, 4.69 and $4.71(\mathrm{~s}, 1 \mathrm{H}), 4.02$ and $4.05(\mathrm{~d}, 1 \mathrm{H}, \mathrm{J}=10.5 \mathrm{~Hz}), 3.91(\mathrm{~d}, 1 \mathrm{H}, \mathrm{J}=10.5 \mathrm{~Hz}), 3.78(\mathrm{~m}, 1 \mathrm{H}), 2.62$ (bs, $1 \mathrm{H}), 1.9-2.15(\mathrm{~m}, 4 \mathrm{H}), 1.35-1.8(\mathrm{~m}, 6 \mathrm{H}), 0.91(\mathrm{~s}, 3 \mathrm{H}), 0.89(\mathrm{~s}, 9 \mathrm{H}), 0.03$ and $0.06(\mathrm{~s}, 6 \mathrm{H})$; IR (neat film, cm. $\left.{ }^{-1}\right)$ : $3123,2112,1701,1253,1105$; MS: $376\left(\mathrm{M}^{+}-\mathrm{N}_{2}\right), 347\left(\mathrm{M}^{+}-\mathrm{t}-\mathrm{Bu}\right)$.

Cyclopropyllactone $\underset{\sim}{3}:$ A solution of diazoester $\underset{\sim}{2}$ (from the experiment described above, $11.44 \mathrm{~g}$, $28.3 \mathrm{mmol}, 1$ equiv) in $607 \mathrm{~mL}$ toluene was added dropwise from a constant rate addition funnel to a mechanically stirred, refluxing solution of bis- $\left(\mathrm{N}-\mathrm{t}\right.$-butylsalicyladiminato)copper (II) catalyst ${ }^{11}(0.63 \mathrm{~g}$, $1.5 \mathrm{mmol}, 0.05$ equiv) in $625 \mathrm{~mL}$ toluene at an initial rate of $60 \mathrm{~mL} / \mathrm{h}$ and after $2 \mathrm{~h}$ at a rate of $42 \mathrm{~mL} / \mathrm{h}$ (total addition time $14 \mathrm{~h}$ ). The solution was held at reflux 20 min after completion of addition, cooled, concentrated and purifled by flash chromatography ${ }^{9}$ ( $2 \%$ triethylamine $-10 \%$ ethyl acetate-hexanes). The yield of purifled lactone $\underset{\sim}{3}$ was $8.93 \mathrm{~g}, 84 \% ;{ }^{1} \mathrm{H} \mathrm{NMR}\left(270 \mathrm{MHz}, \mathrm{CDCl}_{3}\right): \delta 5.6-5.8(\mathrm{~m}, 2 \mathrm{H}), 4.09$ and 4.10 (d, $1 \mathrm{H}, \mathrm{J}=11.5 \mathrm{~Hz}$ ), 3.77 (d, 1H, J=11.5 Hz), 3.50 (bs, 1H), 1.93-2.0 (bs, 3H), 1.5-1.9 (m, 8H), 1.39 and $1.45(\mathrm{~d}, 1 \mathrm{H}, \mathrm{J}=8 \mathrm{~Hz}$ ), 1.18 (d, $1 \mathrm{H}, \mathrm{J}=8 \mathrm{~Hz}), 1.14$ and $1.16(\mathrm{~s}, 3 \mathrm{H}), 0.92$ and $0.93(\mathrm{~s}, 9 \mathrm{H}$ ), 0.06 and $0.07(\mathrm{~s}, 6 \mathrm{H}):$ IR $\left(\mathrm{CCl}_{4}, \mathrm{~cm} .^{-1}\right): 1741 ; \mathrm{MS}$ : $319\left(\mathrm{M}^{+}-\mathrm{t}-\mathrm{Bu}\right)$. 
Cyclopropyllactone 10: A toluene solution of diazoester $\underset{\sim}{9}(10.0 \mathrm{~mL}, 8.94 \mathrm{mg} / \mathrm{mL}, 0.465 \mathrm{mmol})$ was added dropwlse via syringe drive over $16.5 \mathrm{~h}$ to a refluxing solution of bis-(N-t-butylsalicylaldiminato) copper (II) $(10.4 \mathrm{mg}, 0.025 \mathrm{mmol}, 5.4 \mathrm{~mole}$ pct) in toluene $(10.0 \mathrm{~mL})$. After completion of the addition, the solution was held at reflux $30 \mathrm{~min}$, cooled, concentrated 트 vacuo and the residue was purifled by bulb to bulb distillation $\left(110-120^{\circ}, 1.2 \mathrm{~mm}\right)$ giving $72.1 \mathrm{mg}$ yellow liquid product (contaminated with about 1 mole pct t-butylsalicylal dimine, corrected yleld 92\%). The contaminating salicylal dimine can be removed from the lactone by washing an ethereal solution with a small amount of cold dilute hydrochloric acid to provide pure 10 as a colorless oil. ${ }^{1} \mathrm{H}$ NMR $\left(270 \mathrm{MHz} \mathrm{CDCl}_{3}\right): \delta 5.46$ (dd, $1 \mathrm{H}, \mathrm{J}=10,17 \mathrm{~Hz}$ ), 5.04 (d, 1H, J=17 Hz), 5.03 (d, 1H, J=10 Hz), 4.95 (m, 1H), 2.33 (t, 1H, J=6 Hz), 2.1-2.2 (m, 2H), $1.45-2.0(\mathrm{~m}, 5 \mathrm{H})$; IR (neat film, $\left.\mathrm{cm} .{ }^{-1}\right)$ : 1758, 1636; MS: $164\left(\mathrm{M}^{+}\right)$.

The improved methodology reported herein adds considerably to the utllity of the diazoacetate $\longrightarrow$ cyclopropyllactone conversion in synthesis. ${ }^{12}$
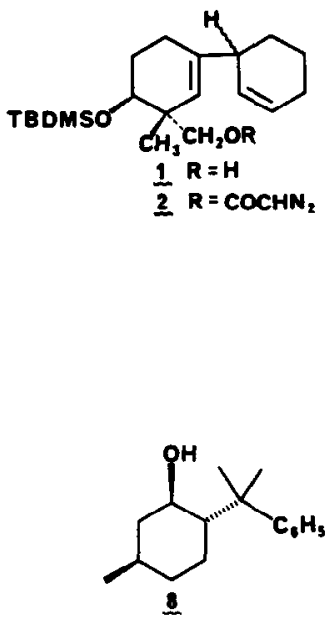

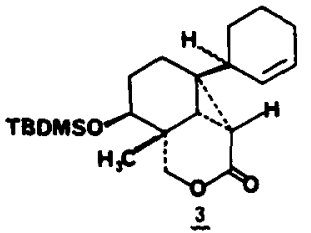<smiles>C=CC1=CC(O)CCC1</smiles>

I $R=H$ $9 \mathrm{R}=\mathrm{COCHN}_{2}$
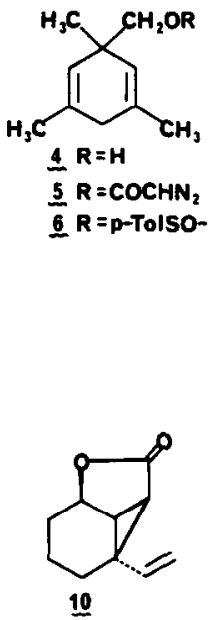

\section{References and Notes}

1. K. Nakanishi, M. Endo, U. Näf, and L. F. Johnson, J. Am. Chem. Soc., 93,5579 (1971).

2. H. O. House, C. J. Blankley, J. Org. Chem., 33, 53 (1968).

3. Prepared in $\mathbf{7 0} \%$ overall yleld by lithium aluminum hydride reduction of the product from reductive Birch alkylation of 3,5-dimethylbenzolc acid; see H. Van Bekkum, C. B. Van Den Bosch, G. Van Minnenpathuis, J. C. DeMos, and A. M. Van Wijk, Rec. Trav. Chim., 90, 137 (1971). 
4. For 5: ${ }^{1}{ }_{\mathrm{HNMR}}\left(80 \mathrm{MHz}, \mathrm{CDCl}_{3}\right): \delta 5.12(\mathrm{bs}, 1 \mathrm{H}), 4.62(\mathrm{~s}, 1 \mathrm{H}), 3.82(\mathrm{~s}, 2 \mathrm{H}), 2.35$ (bs, 2H), $1.70(\mathrm{~s}, 6 \mathrm{H}), 1.00(\mathrm{~s}, 3 \mathrm{H})$; IR meat film, $\left.\mathrm{cm}^{-1}\right)$ : $3112,2112,1701$. For $\underset{\sim}{6:}{ }^{1} \mathrm{H}$ NMR $\left(80 \mathrm{MHz}, \mathrm{CDCl}_{3}\right): \delta 7.60(\mathrm{~d}, 2 \mathrm{H}, \mathrm{J}=8 \mathrm{~Hz}), 7.31(\mathrm{~d}, 2 \mathrm{H}, \mathrm{J}=6 \mathrm{~Hz}), 5.15(\mathrm{~m}, 2 \mathrm{H}), 3.74(\mathrm{~d}, 1 \mathrm{H}$, $J=9 \mathrm{~Hz}), 3.21(\mathrm{~d}, 1 \mathrm{H}, \mathrm{J}=9 \mathrm{~Hz}), 2.43$ (bs, $5 \mathrm{H}), 1.72(\mathrm{~s}, 6 \mathrm{H}), 1.00(\mathrm{~s}, 3 \mathrm{H})$; IR (neat fllm, $\mathrm{cm}^{-1}$ ): 1139.

5. Recently cholesteryl p-toluenesulfinate has been tentatively Identifled as a by-product in the preparation of cholesteryl diazoacetate; see S. A. Keilbaugb and E. R. Thornton, J. Am. Chem. Soc., 105, 3283 (1983).

6. C. J. Blankley, F. J. Sauter and H. O. House, Organic Syntheses, Coll. Vol. V, p. 258; John Wiley, New York (1973).

7. Prepared in 75\% overall yteld from 3-ethoxycyclohex-2-enone by the following sequence: vinylmagnesium bromide, $\mathrm{H}^{+}, \mathrm{NaBH}_{4} / \mathrm{CeCl}_{3}$ (see J. -L. Luche, J. Am. Chem. Soc., $\underline{\underline{100}}$, 2226 (1978)).

8. E. J. Corey and H. E. Ensley, J. Am. Chem. Soc., 97, 6908 (1975). This experiment was performed by Dr. Chi-nung Hsiao.

9. W. C. Still, M. Kahn, and A. Mitra, J. Org. Chem., 43, 2923 (1978).

10. H. Nozaki, H. Takaya, S. Morluti, and R. Noyori, Tetrahedron, 24, 3655 (1968) and H. Hiral and M. Matsui, Agr. Biol. Chem., 40, 169 (1976).

11. Prepared in quantitative yield by the method of R. G. Charles (J. Org. Chem., 22, $677(1957))$. Recrystallization from methanol afforded large, black prisms mp 184-185 (2it mp 185-186 ${ }^{\circ}$ ): calcd for $\mathrm{C}_{22} \mathrm{H}_{28} \mathrm{CuN}_{2} \mathrm{O}_{2}: \mathrm{C}, 63.52 ; \mathrm{H}, 6.78 ; \mathrm{N}, 6.73 ;$ found: C, 63.47; H, 6.64; N, 6.79. (See L. Sacconl and M. Ciampolini, J. Chem. Soc, , 276 (1964)).

12. This research was assisted financially by a grant from the National Science Foundation. (Received in USA 29 May 1984) 